\title{
Synthesis, Cytotoxicity and Topoisomerase II Inhibition Study of New Thioxanthone Analogues
}

\author{
Sangwook Woo, Da-hye Kang, ${ }^{\dagger}$ Jungsook Kim, Chong-Soon Lee, ${ }^{\ddagger}$ Eung-Seok Lee, \\ Yurngdong Jahng, ${ }^{\$}$ Youngjoo Kwon, ${ }^{\dagger}$ and Younghwa Na ${ }^{\circ}$ \\ College of Pharmacy, Catholic Lnwersity of Daegu, Gyeongsan, Gyeongbuk 712-702, Korea. "E-mail: wa7315/acu.ac.kr \\ Division of Life \& Pharmacetitical Sciences, Ewha Womans Lniversity, Seoul 120-750, Korea \\ ${ }_{+}$Department of Biochemistry, College of Natural Sciences, Fetngnam Lniversity, Gyeongsan 71 2-749, Korea \\ $\$$ College of Phamacy leungham Universitv, Gveongsan 712-749, Korea \\ Recened November 15, 2007
}

Key Words : Thioxanthones. Topoisomerase II inhibition. Anti-cancer agents

Xanthone (1) compounds found as secondary metabolites from higher plants and microorganisms have wide biological profiles including anti-hypertensive, anti-oxidative. antithrombotic, and anti-cancer activity, based on their diverse structures. 'The interesting structural scaffold and biological efficacy of xanthones enforced many scientists to synthesize these compounds for the developnient of prospective new drug candidates. Among these xanthones, oxygenated xanthones synthesized or isolated from natural sources revealed effective inhibitory activity against several cancer cell lines. ${ }^{2}$ Especially. 2',3'-epoxyproposy substituted xanthones have efficiently prohibited growth of cancer cells and xanthone (2) possessing two $2^{\prime}, 3^{\prime}$-epoxypropoxy groups at 3 and 5 position showed most active anticancer activity in the series prepared ${ }^{\text {ta. } b}$

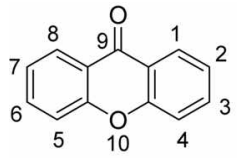

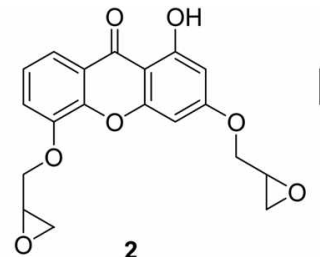

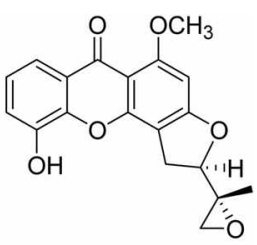

3

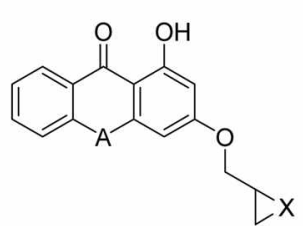

$4 A=0, X=0$

$5 \mathrm{~A}=\mathrm{S}, \mathrm{X}=0$

$6 A=S, X=S$

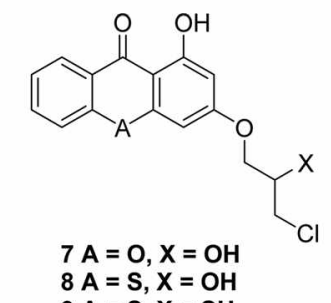

$9 A=S, X=S H$

Psorospermin (3) isolated from African plant is a natural conpound showing good anti-cancer activity against human and murine cancer cell lines. ${ }^{3}$ In the structural viewpoint, 3 also possessed xanthone and 2'.3'-eposyproposy group moieties. Psorospermin has been hlown to show biological activities via intercalation of xanthone group into DNA base pair and alkylation of epoxide by N7-guanine in the presence of topoisomerase $\mathrm{II}^{+}$Topoisomerase II is critical enzyme for cell propagation pathway by mediating DNA double strand cleavage and religation process to relax supercoiled DNA. ${ }^{5}$

Previously we reported that the 2',3'-epoxyproposy xantlones and their ring opened halohydrin analogues showed significant cytotoxic and topoisomerase II relaxation inhibitory activities. These findings suggested that the epoxide ring opened compounds might modulate the biological efficacy of epoxide compounds. According to the literature, replacement of oxygen with sulfur in the xanthone core also changed the phammacological profiles of parent compounds. ${ }^{7}$

In this report. we have synthesized and examined anticancer activities of four new thioxanthone analogues including 2',3'-eposyproposy coupled thioxanthones 5 and 6 and their eposy ring opened halohydrin compounds 8 and 9.

The synthetic method employed for the compounds was depicted in Scheme 1. Thioxanthone core was prepared using phloroglucinol and thiosalicylic acid according to the literature. ${ }^{7 \mathrm{c}}$ Introduction of eposyproposy or thioeposypropoxy group at C3 oxygen position in 1,3-dilyydroxythioxanthone $^{7 c}(\mathbf{1 0})$ was accomplished in the $\mathrm{K}_{2} \mathrm{CO}_{3}$ basic acetone solution. In this step. interestingly, we could not get any bis1.3-(2'.3'-epoxyproposy) substituted compound but separated only C3-monoepoxyproposy substituted thioxanthone compounds, 5 and 6 . These structures are confirmed by comparison of the chemical shift values of the corresponding xanthone $(4)^{6}$ in the ${ }^{1} \mathrm{H}$ and ${ }^{13} \mathrm{C}-\mathrm{NMR}$ spectra. We also observed that two methylene protons of epoxide ring of compound 5 shifted $0.31-0.45$ ppm more down field than those values of compound 6 in the ${ }^{\text {}} \mathrm{H}-\mathrm{NMR}$ spectra. This is the typical pattem between epoxide and thioepoxide ring. Finally, epoxide ring open reactions of 5 and 6 were conducted in aqueous $1 \mathrm{M}$ or $3 \mathrm{M}-\mathrm{HCl}$ in EtOAc to produce chlorohydrin or chlorothiohydrin compounds $\mathbf{8}$ and $\mathbf{9}$ Reaction of compound 6 took much longer time than 5 (ovenight w $30 \mathrm{~min}$ ). which indicates that thioepoxide is more resistant to the nucleophile than epoxide itself under acidic conditions. All the spectral data $\left({ }^{1} \mathrm{H}\right.$ and ${ }^{13} \mathrm{C}$ NMR. COSY, and mass spectra) were consistent with the proposed structures.

Compounds 5. 6, 8. and 9 were tested for the cytotoxicity against several human cancer cell lines using adrianycin as 
<smiles>O=C(O)c1ccccc1S</smiles>

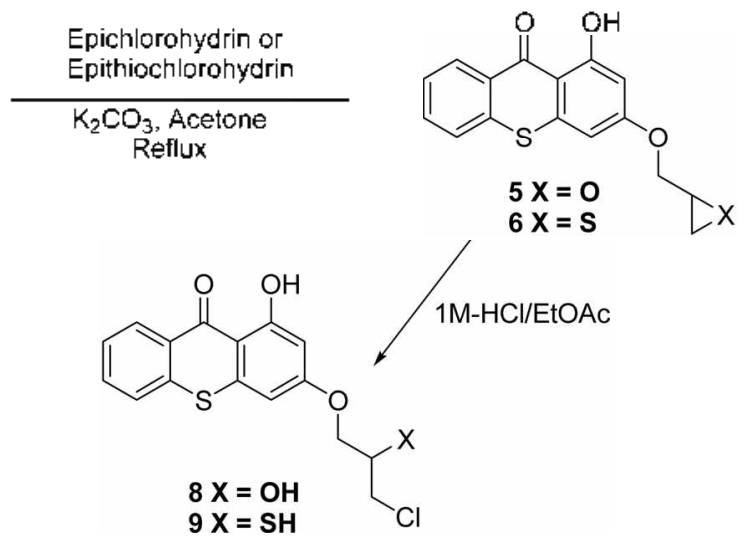

Scheme 1. Synthetic method for target compounds.

a reference. The method applied for the test is typical MTT assay method. The result is indicated in Table 1. Most compounds tested showed significant cytotoxic activity against certain cancer cell lines and compound $\mathbf{5}$. especially. was the most active one which is comparable to the reference. From this result we suspected that the epoxide ring is important for the cytotoxic activity for the compounds tested. When we compared the activities between ring opened compounds 8 and 9. there were not significant activity variations. These cy totoxic results showed that thioxanthone analogues are more active in the anticancer activities than the corresponding xanthone analogues, especially. compound $5 w$ conipound 4.

With these cy totoxicity test results. compounds are screened for the topoisomerase II inhibition function. Topoisomer-

Table 1. Cytotoxic activities of prepared compounds against various human cancer cell lines ( unit: $\ell, M$ )

\begin{tabular}{lccccc}
\hline & Adrianyein & 5 & 6 & 8 & 9 \\
\hline MCF-7 & $18.9 \pm 0.8$ & $50.2 \pm 0.1$ & $>100$ & $32.7 \pm 3.3$ & $>100$ \\
HCT-116 & $4.0 \pm 0.8$ & $5.0 \pm 0.1$ & $22.7 \pm 2.4$ & $>100$ & $31.1 \pm 1.8$ \\
DU-145 & $1.4 \pm 0.2$ & $1.0 \pm 0.2$ & $3.9 \pm 0.3$ & $22.3 \pm 2.9$ & $11.1 \pm 2.4$ \\
HeLa & $10.1 \pm 0.8$ & $42.3 \pm 2.2$ & $>100$ & $>100$ & $>100$ \\
\hline
\end{tabular}

"Each data point represents mean \pm S.D. from three different experiments performed in triplicate. Cell lines used are MCF-7. human breast tumor: HCT 116. human colon tumor: DU 145. human prostate tumor: HeLa. human cervis tumor.

Table 2. Iopoisonerase 11 inhibition rate (\%) of prepared compounds

\begin{tabular}{lccccc}
\hline Comp. conc. & Etoposide & 5 & 6 & 8 & 9 \\
\hline $20 \mu \mathrm{M}$ & 40 & $0\left(40^{\alpha}\right)$ & 0 & 77 & 0 \\
$100 \mu \mathrm{M}$ & 70 & $21\left(81^{\circ}\right)$ & 0 & 84 & 16 \\
\hline
\end{tabular}

"I hese values are the result of etoposide from difterent batch of test.

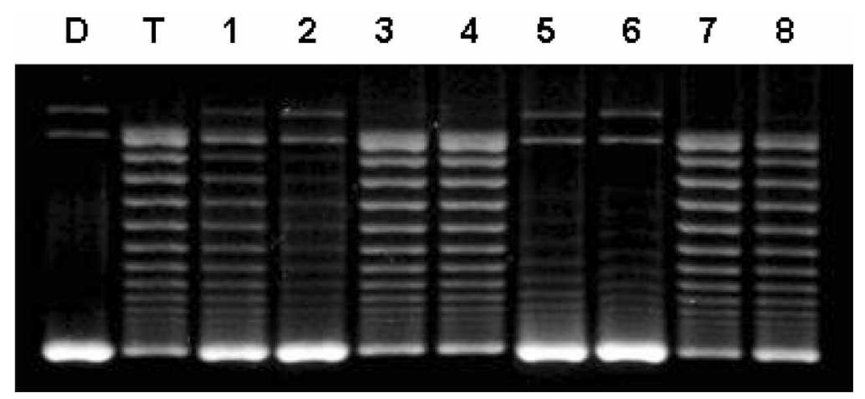

Figure 1. Topoisomerase II inhibition test of prepared compounds. Compounds were examined in a final concentration of $20 \mu \mathrm{M}$ and $100 \mu \mathrm{M}$, respectively. Lane D: pBR 322 only, Lane T: Topo II only, Lane 1-2: etoposide, $20, \mathrm{M}$ and $100 / \mathrm{M}$, Lane 3-4: 6, 20, $/ \mathrm{M}$ and $100 t \mathrm{M}$; Lane 5-6: 8, 20 $t \mathrm{M}$ and $100 t \mathrm{M}$; Lanle 7-8: 9, 20 $t \mathrm{M}$ and $100, M \mathrm{M}$

ase II relasation assay was conducted using human topoisomerase II (Topogen) with etoposide as a positive control The data were analyzed and calculated with LabWork 4.5 Software for the inlibition ratio. The result is described in the Table 2 and Figure 1. Among the compounds, compound 8 showed $77 \%$ inhibition rate against topoisomerase II action at $20 \mu \mathrm{M}$ and $84 \%$ at $100 \mu \mathrm{M}$. The topoisomerase II inhibition of compound $\mathbf{8}$ was superior to etoposide used as reference, almost two times more active at $20 \mu \mathrm{M}$ concentration. This compound was also more potent topoisomerase II inhibitor than the corresponding xanthone analogue $7^{6}$ But other compounds are not active at all. The outcome of topoisomerase II inhibition test revealed that epoxide ring tethered to thioxanthone core did not mediate the topoisomerase II inlubition pathways. But the epoxide ring opened chlorohydrin not chlorothiohydrin enhanced the topoisomerase II inhibition activity of thioxanthone structure.

In conclusion, four thioxanthone analogues were synthesized and tested their biological capacities, cytotoxicity and topoisomerase II inhibition. In the cytotoxicity test compound 5 showed best cytotoxic activity than other compounds tested. But topoisomerase II inhibition test generated different results. Compound $\mathbf{8}$ exerted highly efficient topoisonerase II inhibition activity: $77 \%$ inhibition rate against topoisomerase II action at $20 \mu \mathrm{M}$ and $84 \%$ at 100 $\mu \mathrm{M}$. Nonetheless, cytotoxicity and topoisomerase II inhibition test result have not been correlated with each other in vitro. More works on the SAR for the xanthone and thioxanthone analogues are on going to elucidate the optimized structure and the result will be reported in the near future.

\section{Experimental Section}

The solvents and reactants were of the best commercial grade available and were used without further purification unless noted. TLC plate was Kieselgel $60 \mathrm{~F}_{3: 54}$ (Art A715, Merck) and silica gel for colmmn chromatography was Silica gel 60 (0.040-0.063 mm ASTM. Merck). ${ }^{1} \mathrm{H}$ and ${ }^{13} \mathrm{C}$. NMR spectra were taken on Varian NMR AS $400 \mathrm{MH} /$ instrument. Chemical shifts $(\delta)$ are in parts per million (ppm) 
relative to tetramethylsilane as internal standard. and coupling constants ( $J$ values) are in Hertz. Mass spectral investigations were run on a LCQ advantage-trap mass spectrometer equipped with electrospray ionization (ESI) source at Yeungnam University. Gyeongsan, Korea. Melting points were measured on a Barnstead International MEL-TEMP ${ }^{\text {is }}$ 1202D instrument without correction.

1-Hydroxy-3-(2',3'-epoxypropoxy)thioxanthone (5). To the reaction mixture of compound $10(137 \mathrm{mg} .0 .61 \mathrm{mmol})$ and $\mathrm{K}_{2} \mathrm{CO}_{3}$ (169 $\mathrm{mg}, 1.22 \mathrm{munol}$ ) in anhydrous acetone (15 $\mathrm{mL})$ was added epichlorohydrin $(0.24 \mathrm{~mL}, 3.05 \mathrm{mmol})$ under nitrogen condition. The reaction mixture was refluxed overnight and solvent was removed under reduced pressure. The residue was diluted with ethyl acetate and organic layer was washed with water and brine. successively. After evaporation of solvent, the residue was purified by silica gel column chromatography (eluent: $\mathrm{CH}_{2} \mathrm{Cl}_{2}$ ) to afford yellow solid compound. ( $34 \mathrm{mg}, 18.6 \%$ ): m.p. $160-162{ }^{\circ} \mathrm{C} ; \mathrm{R}_{f} 0.71$ $\left(\mathrm{CH}_{2} \mathrm{Cl}_{3}\right),{ }^{1} \mathrm{H}-\mathrm{NMR}\left(400 \mathrm{MHz}, \mathrm{CDCl}_{3}\right) \delta 2.7 \mathrm{l}$ (dd. $J=2.6$. $4.6 \mathrm{~Hz}, 1 \mathrm{H} . \mathrm{C}^{\prime}-\mathrm{H}_{\mathrm{a}}$ ). 2.87 (dd. $J=3.6 .4 .6 \mathrm{~Hz}, 1 \mathrm{H}, \mathrm{C}^{\prime}-\mathrm{H}_{\mathrm{b}}$ ). $3.30-3.32(\mathrm{~m}, \mathrm{LH} . \mathrm{C}-2 \mathrm{H}), 3.93$ (dd. $J=5.6 .11 .2 \mathrm{~Hz}, \mathrm{LH}$. $\left.\mathrm{Cl}^{\prime}-\mathrm{H}_{\mathrm{a}}\right)+4.26\left(\mathrm{dd}, J=2.8,11.2 \mathrm{~Hz} . \mathrm{lH} . \mathrm{Cl}^{\prime}-\mathrm{H}_{\mathrm{b}}\right) .6 .38(\mathrm{~d}, J=$ $2.6 \mathrm{~Hz} . \mathrm{lH} . \mathrm{C}+\mathrm{H}$ ). 6.53 (d, $J=2.6 \mathrm{~Hz} .1 \mathrm{H}, \mathrm{C} 2-\mathrm{H}) .7 .37 \cdot$ 7.43 (m, 2H. C5. 7-H). 7.53 (ddd, $J=1.4,7.6 .11 .3 \mathrm{~Hz}, 1 \mathrm{H}$. C6-H). 8.47 (dd. $J=1.4,8.2 \mathrm{~Hz}, \mathrm{lH}, \mathrm{C} 8-\mathrm{H}):{ }^{13} \mathrm{C}-\mathrm{NMR}(100$ $\left.\mathrm{MHz} . \mathrm{CDCl}_{3}\right) 43.6,48.7,68.0 .99 .0 .101 .2 .108 .6,124.4$. 127.2. 128.2, 131.6, 131.6, 136.1, 139.4, 162.4, 166.4. 183.2 ppin: LC-ESI: $m e$ 301.1 [M+1]

1-Hydroxy-3-(2',3'-thioepoxypropoxy)thioxanthone (6). To the reaction mixture of compound $\mathbf{1 0}$ ( $100 \mathrm{mg}, 0.41$ mmol) and $\mathrm{K}_{2} \mathrm{CO}_{3}$ (113 $\mathrm{mg} .0 .82 \mathrm{mmol}$ ) in anhydrous acetone $(15 \mathrm{~mL})$ was added epithiochlorohydrin $(0.22 \mathrm{~g}$. $2.05 \mathrm{mmol}$ ) under nitrogen condition. The reaction mixture was refluxed ovenight and solvent was removed under reduced pressure. The residue was diluted with ethyl acetate and organic layer was washed with water and brine, successively. After evaporation of solvent. the residue was purified by silica gel column chromatography (eluent:ethyl acetate/ $n$-hexane $=1: 1$ ) to afford yellow green solid compound. (43 mg. $33.3 \%$ ): m.p. $148-150{ }^{\circ} \mathrm{C}: \mathrm{R}_{f} 0.89$ (ethyl acetate/ $n$-hexane $=1: 1):{ }^{1} \mathrm{H}-\mathrm{NMR}\left(400 \mathrm{MHz} . \mathrm{CDCl}_{3}\right) \delta 2.27$ (dd. $J$ $\left.=1.4 .5 .7 \mathrm{~Hz}, 1 \mathrm{H}, \mathrm{C} 3^{\prime}-\mathrm{H}_{\mathrm{a}}\right), 2.56\left(\mathrm{~d} . J=5.7 \mathrm{~Hz} \cdot 1 \mathrm{H} . \mathrm{C}^{\prime}-\mathrm{H}_{\mathrm{b}}\right)$. $3.16-3.2 \mathrm{l}(\mathrm{m}, 1 \mathrm{H}, \mathrm{C}-2 \mathrm{H}) .3 .92(\mathrm{dd}, J=7.2 .10 .0 \mathrm{~Hz} . \mathrm{lH}$. $\left.\mathrm{Cl}^{\prime}-\mathrm{H}_{\mathrm{a}}\right), 4.13\left(\mathrm{dd}, J=5.6 .10 .0 \mathrm{~Hz}, 1 \mathrm{H}, \mathrm{Cl} '-\mathrm{H}_{\mathrm{b}}\right), 6.12(\mathrm{~d}, J=$ $2.4 \mathrm{~Hz}, \mathrm{IH} . \mathrm{C}+\mathrm{H}) .6 .50$ (d, $J=2.4 \mathrm{~Hz}, 1 \mathrm{H} . \mathrm{C} 2-\mathrm{H}), 7.36$ (ddd $J=1.4 .6 .8 .7 .8 \mathrm{~Hz}, 1 \mathrm{H} . \mathrm{C} 7-\mathrm{H}) .7 .37$ (d. $J=8.2 \mathrm{~Hz}$. lH. C5-H). 7.49 (ddd. $J=1.6 .8 .0 .8 .2 \mathrm{~Hz} .1 \mathrm{H} . \mathrm{C} 6-\mathrm{H}$ ). 8.43 (dd. $J=1.4 .7 .8 \mathrm{~Hz}, 1 \mathrm{H}, \mathrm{C} 8 \mathrm{-H}):{ }^{13} \mathrm{C}-\mathrm{NMR}(100 \mathrm{MHz}$. $\left.\mathrm{CDCl}_{3}\right)$ 24.0. 31.0. 72.9, 100.2, 102.2, 109.8. 125.6. 126.5. 128.4. 129.4, 132.8. 137.3. 140.6. 163.4. 167.5. $184.3 \mathrm{ppm}$ : LC-ESI: $m e$ e $317.1[\mathrm{M}+1]^{-}$.

1-Hydroxy-3-(3'-chloro-2'-hydroxy-1'-propoxy)thioxanthone (8). Compound 5 (13 $\mathrm{mg}, 0.04 \mathrm{mmol}$ ) was dissolved in aqueous ethyl acetate $1 \mathrm{M}-\mathrm{HCl}(3 \mathrm{~mL})$ and this solution was stirred for $30 \mathrm{~min}$ at room temperature. The solvent was removed under reduced pressure and the residue was dried under vacuum to give yellow solid compound. $(14 \mathrm{mg}$.
96.0\%): m.p. $150-152{ }^{\circ} \mathrm{C}:{ }^{1} \mathrm{H}-\mathrm{NMR}\left(400 \mathrm{MHz} . \mathrm{CDCl}_{3}\right) \delta$ $3.68-3.75\left(\mathrm{~m}, 2 \mathrm{H}, \mathrm{C} 3^{\prime}-\mathrm{H}\right), 4.11\left(\mathrm{~m}, 2 \mathrm{H}, \mathrm{Cl}^{\prime}-\mathrm{H}\right), 4.18-4.22$ $(\mathrm{m}, \mathrm{l} \mathrm{H} . \mathrm{C}-2 \mathrm{H}), 6.39$ (d. $J=2.4 \mathrm{~Hz}, \mathrm{lH}, \mathrm{C} 4-\mathrm{H}), 6.53$ (d. $J=$ $2.4 \mathrm{~Hz}$. 1H. C. $2-\mathrm{H}$ ), 7.39-7.45 (m, 2H. C5, 7-H), 7.54 (ddd. $J$ $=1.2 .7 .5 .7 .5 \mathrm{~Hz}, 1 \mathrm{H}, \mathrm{C} 6-\mathrm{H}), 8.49(\mathrm{dd}, J=1.2 .8 .4 \mathrm{~Hz} . \mathrm{lH}$, C8-H): ${ }^{13} \mathrm{C}-\mathrm{NMR}\left(100 \mathrm{MHz} . \mathrm{CDCl}_{3}\right)+6.0\left(\mathrm{C}^{\prime}\right), 69.0\left(\mathrm{Cl}^{\prime}\right)$, $69.7\left(\mathrm{C}^{\prime}\right) .100 .3(\mathrm{C} 4) .102 .2(\mathrm{C} 2), 110.0(\mathrm{C} 9 \mathrm{a}) .125 .6(\mathrm{C} 5)$. 126.6 (C7). 128.4 (C8a), 129.5 (C8), 132.9 (C6). 137.3 $(\mathrm{ClOa}) .140 .8(\mathrm{C} 4 \mathrm{a}) .163 .3(\mathrm{Cl}) .167 .6(\mathrm{C} 3), 184.4(\mathrm{C} 9)$ ppm: LC.ESI: $m e 337.3[\mathrm{M}+1]^{+}$.

1-Hydroxy-3-(3'-chloro-2'-thioyl-1'-propoxy)thioxanthone (9). Compound 5 (30 $\mathrm{mg}, 0.09 \mathrm{mmol}$ ) was dissolved in aqueous ethyl acetate $3 \mathrm{M}-\mathrm{HCl}(3 \mathrm{~mL})$ and this solution was stirred at room temperature overnight. The solvent was removed under reduced pressure and residue was dried under vacuum to give yellow solid compound. ( $30 \mathrm{mg}$. 89.9\%): m.p. $133-134{ }^{\circ} \mathrm{C}:{ }^{1} \mathrm{H}-\mathrm{NMR}\left(400 \mathrm{MHz} . \mathrm{CDCl}_{3}\right) \delta$ $2.12\left(\right.$ d. $\left.J=10.0 \mathrm{~Hz}, 1 \mathrm{H} . \mathrm{C} 2^{\prime}-\mathrm{SH}\right) .3 .37-3.42\left(\mathrm{~m}, \mathrm{lH}, \mathrm{C}-2^{\prime} \mathrm{H}\right)$, 3.84 (dd. $J=6.8 .11 .3 \mathrm{~Hz} . \mathrm{LH} . \mathrm{C} 3^{\prime}-\mathrm{H}_{\mathrm{a}}$ ). 3.97 (dd. $J=4.2$, $\left.11.3 \mathrm{~Hz}, 1 \mathrm{H}, \mathrm{C} 3^{\prime}-\mathrm{H}_{\mathrm{b}}\right), 4.20$ (dd. $J=6.0,9.6 \mathrm{~Hz}, 1 \mathrm{H} . \mathrm{Cl}^{\prime}-\mathrm{H}_{\mathrm{a}}$ ), 4.35 (dd. $\left.J=4.4,9.6 \mathrm{~Hz} . \mathrm{lH} . \mathrm{Cl}^{\prime}-\mathrm{H}_{\mathrm{b}}\right) .6 .45$ (d. $J=2.2 \mathrm{~Hz}$, lH. C4-H), 6.59 (d. $J=2.2 \mathrm{~Hz}$. IH. C2-H), 7.26-7.51 (m, $2 \mathrm{H} . \mathrm{C} 5.7 \cdot \mathrm{H}) .7 .6 \mathrm{l}(\mathrm{ddd}, J=1.2,7.4 .7 .5 \mathrm{~Hz} .1 \mathrm{H}, \mathrm{C} 6 \mathrm{-H})$, 8.55 (d. $J=7.6 \mathrm{~Hz} .1 \mathrm{H}, \mathrm{C} 8 \mathrm{-H}) ;{ }^{13} \mathrm{C} \cdot \mathrm{NMR}(100 \mathrm{MHz}$, $\left.\mathrm{CDCl}_{3}\right) 40.0 .46 .9 .69 .0,100.3,102.3,110.0,125.6,126.6$, $128.4,129.4,132.9 .137 .3,140.7 .163 .2,167.6,184.4 \mathrm{ppm}$ : LC-ESI: $m e$ e $353.1[\mathrm{M}+1]^{+}$.

Cytotoxicity Test. Cytotoxicity was determined by MTT assay. Cancer cells were purchased from the American Tissue Culture Collection (Rockville, MD) and cultured according to the supplier's instructions. $2.4 \times 10^{4}$ cells per well in 96-well microplates were attached overnight in 0.1 $\mathrm{mL}$ of media supplied with $10 \%$ Fetal Bovine Serum (Welgene, Korea) under $5 \% \mathrm{CO}_{2}$ in a humidified atmosphere at $37^{\circ} \mathrm{C}$. On day 1 , culture medium in each well was exchanged with $0.1 \mathrm{~mL}$ aliquots of medium containing graded concentrations of compounds 5.6.8, and 9. On day 4, each well was added by the MTT (Sigma) solution (final concentration $0.5 \mathrm{mg} / \mathrm{mLL}$ in media) then incubated for additional 4 $\mathrm{h}$ under the same condition. Culture medium in each well was discarded and replaced with $0.1 \mathrm{~mL}$ of dissolving solution (DMSO). The absorbance of each well was determined by an Automatic Elisa Reader System (Bio-Rad 3550 ) with a $570 \mathrm{~nm}$ wavelength. For determination of the I $C_{5 i j}$ values, the absorbance readings at $570 \mathrm{~mm}$ were fitted to the four-parameter logistic equation.

Assay for DNA Topoisomerase II Inhibition in vitro. DNA topoisomerase II inhibition was measured by assessing relaxation of supercoiled pBR322 plasmid DNA. The reaction mixture contained $50 \mathrm{mM}$ Tris- $\mathrm{HCl}(\mathrm{pH} 8.0), 120$ $\mathrm{mM} \mathrm{KCl} .10 \mathrm{mM} \mathrm{MgCl}$. $0.5 \mathrm{mM}$ ATP. $0.5 \mathrm{mM}$ dithiothreitol. $30 \mu \mathrm{g} / \mathrm{mL}$ bovine serum albumin, $0.2 \mu \mathrm{g}$ pBR322 plasmid DNA. $0.3 \mathrm{U}$ human DNA topoisomerase II $\alpha$ (TopoGEN), and test compounds in a final volume of $20 \mu \mathrm{L}$. The reactions were incubated for $30 \mathrm{~min}$ at $37^{\circ} \mathrm{C}$ and terminated by the addition of $3 \mu \mathrm{L}$ of solution containing $0.77 \%$ sodium dodecyl sulfate, and $77 \mathrm{mM}$ EDTA. Samples 
were mixed with $2 \mu \mathrm{L}$ of solution containing $30 \%$ sucrose. $0.5 \%$ bromophenol blue and $0.5 \%$ xylene cyanol, and subjected to electrophoresis on a $1 \%$ agarose gel at $1.5 \mathrm{~V} / \mathrm{cm}$ for $10 \mathrm{~h}$ with a runiming buffer of Tris-borate-EDTA. Gels were stained for $30 \mathrm{~min}$ in an aqueous solution of ethidium bromide $(0.5 \mu \mathrm{g} / \mathrm{mLL})$. DNA bands were visualized by transillumination with UV light and quantitated by an inage analyzer and LabWork 4.5 software (UVP)

Acknowledgements. This work was supported by the Korea Research Foundation Grant funded by the Korean Govenument (MOEHRD) (KRF-2006-521-E00159). Da-hye Kang was supported by the second stage of the Brain Korea 2I Project.

\section{References and Notes}

1. (a) Pinto. M. M. M: Sousa. M. E.: Nascimento, M. S. I. Curf. Hed. them. 2005, 12, 2517. (b) Peres. V: Nagem. T. J; de Oliveira. F. F. Phytochemistry 2000, 55. 683. (c) Wang. L.-W.: Kang. J.-J.: Chen. I.-J.: Teng. C.-M.: Lin. C.-N. Bioorg. Med. Chem. 2002. 10.567. (d) Lin. C.-N.: Liou. S.-S.: Ko. F.-N.: Teng. C.-M. J. Pharm. Sir. 1992. \$1. 1109. (e) Lin. C.-N.: Liou. S.-S.:
Ko. F.-N.: Teng. C.-M. J. Pham. Sci. 1993. 82.11.

2. (a) Lion. S.-S.: Shieh. W.-L.: Cheng. T.-H.: Won. S.-T.: Lin. C.-N. J. Pham Pharnacol 1993. 45. 791. (b) Lin. C.-N.: Liou. S.-S.: Lee. T.-H.; Chuang. Y.-C.; Won. S.-J J. Pham. Phamacol 1996. 48. 539. (c) Pedro. M. Cerqueira, F.: Sousa M. E.: Nascimento. M. S. J.: Pinto. M. Bioong. 11ed. Chem. 2002, 10. 3725. (d) Saraiva. L.: Fresco. P.: Pinto. E.: Sousa. E.: Pinto. M.: Goncalves. J. Bioong. Med. Chem. 2003. H. 1215. (e) Zhou. Y.-S.: Hou. A.-T.: Zhu. G.-F.: Chenl. Y.-F.: Sun. H.-D.: Zhao. Q.-S. Bioong. Med. Chem. 2004, 12, 1947.

3. (a) Kupchan, S. M.: Streelman. D. R.: Sneden, A. T. J. Nat. Prod 1980. 13, 296. (b) Cassady. J. M. J. Nat. Prod. 1990, 53, 23.

4. (a) Hansen. M.: Lee. S.-J.: Cassady. J. M.: Hurley. L. H. J. An. Chent. Sac. 1996. 118. 5553, (b) Kwok. Y.: Hurley. L. H. J. Biol. Chent 1998. 273.33020

5. (a) Forterre. P: Gribaldo. S:; Gadelle. D; Serre. M. C. Biochimie 2007. 89, 427. (b) Schvartzman, J. B.: Stasiak. A. E1 $I B O 2004,5$ 256. (c) Holden. J. A. Cur ifed Chem Anticancer Agents 2001. 1. 1.

6. Woo. S.: Tung. J.: Lee. C.: Kwonl. Y.: Na. Y. Bioorg. Hed. Chent. Lett. 2007. 17. 1163.

7. (a) Kostakis. I. K:: Magiatis. P.: Pouli. N.: Marakos. P.: Skaltsounis, A.-L.: Pratsinis, H.: Leonce. S.: Pierre, A. J. Med. Chem. 2002. 45. 2599. (b) Kostakis, I. K.: Ghirtis. K.; Pouli. N.; Marakos. P: Skaltsounis, A.I.; Leonce, S.: Caignard, D. H. Atassi. G. IL Formaco 2000. 55.455. (c) Kostakis. I. K.: Magiatis. P.: Pouli. N.: Marakos. P.: Mikros. E.: Skaltsounis. A.-L.: Leonce. S.: Atassi. G.: Retard. P. Bioorg. Med. Chem, 2001. 9. 2793. 